\title{
Sustaining Social Protection and Provision: the front line in the battle for the Good Society
}

Sustentando a Proteção e a Provisão Social: a linha de frente na batalha pela "Boa Sociedade"

\footnotetext{
${ }^{1}$ Department of Sociology, University of California. 100 Academic Hall \# 1234. Berkeley CA EUA. pevans@berkeley.edu
}

\begin{abstract}
In an era when social policy priorities are subordinated to regressive capitalist agendas, sustaining collective commitments to social protection and social provision defines the front line of the battle for the good society. The conflict manifests itself across a range of arenas, but health is analytically archetypal. This introductory article for the special issue assumes the dynamics of the contradiction between the inherently collective character of health provision and capitalist insistence on using individual consumption valued in market prices to measure societal success. Left unchecked, the elite bloc whose agenda is defined by pursuit of the interests of capital will destroy existing social provision and protection, making societies, especially in the Global South, ugly places to live for ordinary citizens. The articles in this volume leave us with a challenge: how can we construct the oppositional agency necessary to expand and strengthen social provision and protection in an era of regressive capitalist domination?
\end{abstract}

Key-words Social policy, Social protection, Health, Capitalism, Agency
Resumo Em uma era em que as prioridades da política social estão subordinadas a agendas capitalistas regressivas, sustentar compromissos coletivos com a proteção e a provisão social define a linha de frente da batalha para a "boa sociedade". O conflito se manifesta em uma série de arenas, mas a saúde é um arquétipo analítico. $O$ artigo, de caráter introdutório ao número especial, assume a dinâmica da contradição entre o caráter inerentemente coletivo da provisão em saúde e a insistência capitalista em usar o consumo individual valorado em preços de mercado para medir o sucesso de uma sociedade. Deixado sem controle, o bloco de elite cuja agenda é definida pela busca dos interesses do capital destruirá a proteção e a provisão social existentes, tornando as sociedades, especialmente no Sul Global, lugares ruins para os cidadãos comuns viverem. Os artigos deste volume deixam um desafio: como construir a agência necessária para expandir e fortalecer a proteção e provisão social em uma era de dominação capitalista regressiva?

Palavras-chave Política social, Proteção social, Saúde, Capitalismo, Agência 


\section{Introductory Comments}

In an era when social policy priorities are subordinated to regressive capitalist agendas, sustaining collective commitments to social protection and social provision defines the front line of the battle for the good society. The conflict manifests itself across a range of arenas, but health is analytically archetypal. In this introduction, I will use health as the primary lens for thinking about the array of social policies analyzed in the articles of this special issue.

When societies succeed in improving health, human flourishing and societal well-being increase. Accumulating improvements in health have constituted global victories for human flourishing for at least two hundred years. Retreat from efforts to improve health diminishes the capability of members of society to enjoy the lives they value and undermines the collective capacity of societies to achieve their goals. Why then are societies around the globe threatened by regressive policies in health and other social arenas, despite increasing technological progress and growing global wealth?

The articles in this special issue help elucidate this puzzle. They explore policy arenas that share the basic logic of the conflict between social provision and capitalist priorities. They explicate comparative variations in this conflict across developed and developing countries, with an emphasis on the countries of the Global South, especially Brazil.

The dynamics of the contradiction between improving health and remaining faithful to the dictums of capitalist political economy are worth reiterating. The core contradiction is between the inherently collective character of health provision and capitalist insistence on using individual consumption valued in market prices to measure societal success. Key health services have always been provided as collective goods. From sewers and water supplies and public sanitation to vaccines and the eradication of disease bearing vectors like mosquitoes, collective provision forms the foundation of health.

The contradiction is intensified by the fact that those who own capital also have political power, both globally and nationally. Consequently, the formulation and implementation of policy disproportionately reflect the interests of the owners of capital. Increasing the returns to capital is their priority. Consolidating capital's control over political culture and political institutions is an essential complement.

The resulting political culture both supports and reflects a political economy in which health is commodified. The cultural assumption that the improvement of health depends primarily on the provision of "health goods," best thought of as commodities purchased by individuals, makes the construction of health systems whose major consequence is to generate profits for capital seem "natural." At the same time, the power of capital over cultural production includes the capacity to formulate and promulgate these understandings and beliefs, reinforcing the status of commodified health as "natural."

The authors of the studies in this volume explore this basic contradiction across a range of theoretical formulations, engaging a rich variety of concrete evidence. They show how combining the assumption that health is a commodity with the assumption that health provision should be designed to serve the interests of capital constitutes the central obstacle to making societies healthier. Recognizing the power of these combined assumptions leads toward pessimistic projections. Nonetheless, the comparative and historical perspective of the collection also reveals the surprising resilience of social provision.

Their comparative analyses confirm prior work on the institutional configurations that support positive outcomes. Looking across Europe and Latin America, Huber and Niedzwiecki reaffirm the importance of democratic politics, strong left parties and labor movements, not just in constructing more effective institutions of social provision and protection, but also in enabling these institutions to resist attacks. Kerstenetzky and Guedes use recent data on expenditure levels in the OECD countries to reinforce the theme of resistant institutions. They show that social expenditures have increased in recent decades, supported by increased taxes. Even in Latin America, as Machado outlines, public 
health systems continue to provide members of society with access, despite the dynamic expansion of private provision.

In the case of Brazil, the underlying legal infrastructure supporting social provision and protection has been under attack ever since the surprising success of public health advocates in enshrining the right to health care in the 1988 constitution. Presidents Luiz Inácio Lula da Silva and Dilma Rousseff succeeded in expanding provision and protection despite these attacks, but the rapidity of the shift to a negative trajectory once President Rousseff was impeached revealed the fragility of the political and institutional edifice that the Workers' Party had constructed.

Is it possible to reverse the regression in Brazil and more generally in the Global South? The historic role of left political parties and the labor movement makes the importance of revitalizing them clear, but more specific connections between social movements and social policy outcomes are not highlighted. There are surprisingly few sign posts in these articles pointing toward paths to renewed collective agency. Indeed, Sposati is insistent that in Brazil neither social demands nor social movements played a significant role in the institutionalization of social protection. But, this perspective may be too bleak.

Comparative historical research on the politics of health policy suggests that synergistic alliances between social movements, political parties and actors within the state has played a central role in fostering late $20^{\text {th }}$ century progress around the world ${ }^{1}$. Brazil boasts a particularly impressive example: the Sanitarista Movement. The Sanitaristas not only played an important role in fighting for the incorporation of access to health in the 1988 Constitution, but also inserted themselves into key policy-making positions at the municipal level and managed to use these positions, in alliance with sympathetic politicians, to increase health access and reduce infant mortality ${ }^{2}$.

The case of the Sanitarista movement suggests some plausible strategies for exercising agency on behalf of social policy. First, solidarity based on the combination of professional and ideological identities can be a powerful building block. The Sanitaristas' shared identity as doctors dedicated to public health, with public health defined as requiring political and institutional change, was crucial to the strength of the movement. But, solidarity among individuals with shared identity and ideology is not enough. It must be complemented by the construction of networks and movement organizations, and "public interest groups" with nationwide reach, in this case groups like the Brazilian Center for Health Studies (CEBES) and the Brazilian Public Health Association (ABRASCO). It also requires alliances with sympathetic political parties. Finally, in Gibson's (2018) words: "Sanitaristas were self-consciously Gramscian in strategically seeking to occupy state offices in what many describe as a perpetual war of position to embed core ideological tenets within the practice of the democratic state."

Thinking about the Sanitaristas' story in relations to current struggles raises two questions. The first is whether identities in other professions associated with social provision can provide similar solidarity and political leverage. To take the obvious example, is it possible for teachers to exercise comparable agency in relation to education? If so, how? And if not, why not? The second question is even more crucial to assessing the Sanitaristas' relevance in the regressive contemporary environment. To what extent did the Sanitaristas success depend on the complementary context of rising labor mobilization and cross-class solidarities generated by shared opposition to authoritarian rule? If it did, it suggests that effective agency requires the simultaneous construction of different movements that can together constitute an ecology of agency.

The articles in this volume diagnose the contemporary crisis of social protection and provision. Left unchecked, the elite bloc whose agenda is defined by pursuit of the interests of capital will destroy existing social provision and protection, making societies, especially in the Global South, ugly places to live for ordinary citizens, meaner, more divided and more susceptible to destructive appeals to reactionary "identity politics." These articles also leave us with a challenge: how can we construct the oppositional agency necessary to expand and strengthen social provision and protection in an era of regressive capitalist domination? 


\section{References}

1. McGuire JW. Wealth, Health, and Democracy in East Asia and Latin America. New York: Cambridge University Press; 2010.

2. Gibson CL. Movement-Driven Development: The Politics of Health and Democracy in Brazil. Stanford: Stanford University Press; 2018 [forthcoming in December]

Artigo apresentado em 15/05/2018

Aprovado em 22/05/2018

Versão final apresentada em 01/06/2018 